\section{Turnera diffusa 'Luisa', a Drought-tolerant Small Shrub for Warm Climates}

\author{
Alan W. Meerow ${ }^{1}$ and Tomás Ayala-Silva \\ USDA-ARS-SHRS, National Germplasm Repository, 13601 Old Cutler Road, \\ Miami, FL 33158 \\ Brian M. Irish \\ USDA-ARS-TARS, National Germplasm Repository, 2200 Pedro Albizu-Campos \\ Avenue, Suite 201, Mayaguez, Puerto Rico, 00680
}

Additional index words. Turneraceae, Puerto Rico, tropical shrubs, ornamentals, landscape

Turnera L. (Turneraceae or Passifloraceae sensu AGP, 2009) is a genus of 50 to 60 species of predominantly American tropical herbs and shrubs (Mabberly, 1997). Two species are fairly well known in tropical horticulture, T. ulmifolia L. and the related T. subulata Smith (Llamas, 2003). A single cultivar, El Dorado, is listed under T. ulmifolia (Armitage, 2004), although we could not find any data that distinguish it from the species in general.

Turnera diffusa Willd. is a widespread and variable species found throughout tropical America. Commonly known as "damiana," it has figured extensively in folk medicine (Messer, 1991; Zhao et al., 2007) and is noted in particular for its aphrodisiacal properties for which there is scientific support (Arletti et al., 1998; Estrada-Reyes et al., 2009). In this article, we describe a cultivar of $T$. diffusa with outstanding ornamental qualities selected from a population in Puerto Rico.

\section{Origin}

In 2005, the authors conducted a plant exploration in Puerto Rico for species with ornamental potential. In the coastal mogotes (limestone hills) of southern Peñuelas $\mathrm{Mu}-$ nicipality, we encountered a population of T. diffusa. The population was striking for its small, densely pubescent gray-green leaves that we perceived as more attractive than typical of the species elsewhere across its broad range. One individual in the population appeared particularly compact. Cuttings of this individual were collected and placed on a mist propagation

Received for publication 3 Sept. 2010. Accepted for publication 4 Oct. 2010.

We thank Dale Stennett and Carol Lee for technical assistance and the USDA-ARS National Plant Germplasm System Plant Exploration Office for funding our collecting trip in Puerto Rico.

Mention of a trademark, proprietary product, or vendor does not constitute a guarantee or warranty of the product by the U.S. Department of Agriculture and does not imply its approval to the exclusion of other products or vendors that may be suitable.

${ }^{1}$ To whom reprint requests should be addressed; e-mail alan.meerow@ars.usda.gov. facility at the USDA-ARS Tropical Agricultural Research Station in Mayaguez. Once rooted, these were shipped to the National Germplasm Repository at the Subtropical Horticulture Research Station in Miami where we have propagated and evaluated the plant for the past 5 years.

\section{Description}

Size measurements were derived from plants grown in the field for at least 1 year. Color was evaluated with the Royal Horticultural Society (RHS) Horticultural Color Charts (Royal Horticultural Society, 1995) and a Minolta CR-400 colorimeter (KonicaMinolta, Ramsey, NJ) at CIE D65/2 $2^{\circ}$ illumination/viewer conditions as described in Ayala-Silva and Meerow (2006), Ayala-Silva et al. (2005), and Meerow and Ayala-Silva (2008). Twenty measurements were recorded and averaged.

Turnera diffusa 'Luisa' (Figs. 1-4) is a multistemmed, densely branched evergreen subshrub growing to $\approx 0.75 \mathrm{~m}$ tall. The branches radiate from the central stem at an acute angle. One- to 2-year-old twigs are herbaceous and white-pubescent, 0.8 to $1.2 \mathrm{~mm}$ in diameter, RHS grayed green 191C, and turning brown as they age and eventually glabrous; 3 -yr-old branches become woody, 1.7 to $2.2 \mathrm{~mm}$ in diameter, with small ovate-lanceolate lenticels. The central stem ultimately reaches up to $2.5 \mathrm{~cm}$ in diameter at the base and becomes somewhat corky. Leaves are alternate, simple, 13 to $16 \mathrm{~mm}$ long, 4.5 to $5.5 \mathrm{~mm}$ wide, and subsessile to shortly petiolate; the petiole is less than $2.0 \mathrm{~mm}$ long; laminae are narrowly oblanceolate; the margins crenate-sinuate and undulate, white pubescent on both surfaces, pinnately netveined, the veins deeply impressed adaxially, conspicuously embossed abaxially, RHS grayed green 191B adaxially ( $\mathrm{L}^{*}=$ $59.53 \pm 4.54, a^{*}=-9.74 \pm 0.50, b^{*}=15.10 \pm$ 2.42 ) and RHS grayed green $191 \mathrm{C}$ abaxially $\left(\mathrm{L}^{*}=58.43 \pm 6.92, \mathrm{a}^{*}=-7.36 \pm 1.91, \mathrm{~b}^{*}=\right.$ $16.60 \pm 3.27$ ), obtuse at the apex, and attenuate to the short petiole, and aromatic when crushed. The flowers are borne singly in the axils of the more terminal leaves on short slender pedicels 1.5 to $2.0 \mathrm{~mm}$ long, subtended by two laneco- late bracteoles, 4.0 to $5.0 \mathrm{~mm}$ long and $\approx 1.0 \mathrm{~mm}$ wide. The flowers are actinomorphic and rotate, each lasting $1 \mathrm{~d}$, and $12.53 \pm 1.11$ $\mathrm{mm}$ wide. The calyx is 6.0 to $7.0 \mathrm{~mm}$ long and 2.0 to $3.0 \mathrm{~mm}$ wide, consisting of five sepals fused in the lower two-thirds, the free portions lanceolate and acute at the apex, and RHS yellow-green 154D $\left(\mathrm{L}^{*}=84.66 \pm 2.58\right.$, $\left.\mathrm{a}^{*}=-4.20 \pm 0.38, \mathrm{~b}^{*}=24.18 \pm 6.27\right)$. The corolla consists of five petals fused below into a short tube, 1.5 to $2.0 \mathrm{~mm}$ wide, and RHS yellow-orange $14 \mathrm{~A}\left(\mathrm{~L}^{*}=72.47 \pm 1.06\right.$, $\left.\mathrm{a}^{*}=3.59 \pm 1.33, \mathrm{~b}^{*}=59.33 \pm 5.23\right)$; each petal is $5.60 \pm 0.43 \mathrm{~mm}$ long and $4.12 \pm 0.15$ $\mathrm{mm}$ wide and cleft at the apex. The five filiform stamens are 5.0 to $5.4 \mathrm{~mm}$ long and the versatile anthers 0.7 to $1.0 \mathrm{~mm}$ long and yellow. There are three styles, 1.3 to $1.5 \mathrm{~mm}$ long, each three- to four-branched in the apical half. The superior ovary is ovoid, $2 \mathrm{~mm}$ long, and hirsute. The mature fruit has not been observed but is presumed as for the species: small three-valved capsule, 3.0 to $4.0 \mathrm{~mm}$ long, seeds curved, pyriform, and 1.5 to $2.0 \mathrm{~mm}$ long.

The cultivar name 'Luisa' honors the late mother of the second author, who was an enthusiastic admirer of Puerto Rico's native flora.

\section{Cultural Notes}

Turnera diffusa 'Luisa' is readily propagated from softwood cuttings throughout the year. We have found that cuttings from actively growing plants treated with a 5-s basal end dip in 1000 ppm indole butyric acid in $50 \% \mathrm{EtOH}$ root within 4 to 6 weeks when placed under intermittent mist.

We have successfully grown the cultivar in 5 parts aged pine bark: 4 coconut coir dust: 1 coarse sand (by volume) amended with $5.0 \mathrm{~kg} \cdot \mathrm{m}^{-3} 17 \mathrm{~N}-2.3 \mathrm{P}-10 \mathrm{~K}$ Nutricote (Florikan, Sarasota, FL), $4.2 \mathrm{~kg} \cdot \mathrm{m}^{-3}$ dolomite, and $1.2 \mathrm{~kg} \cdot \mathrm{m}^{-3}$ Micromax (Scott's, Milpitas, CA). Rooted cuttings in cell packs are placed directly into $15-\mathrm{cm}$ containers. The plants grow rapidly and would be saleable in $15-\mathrm{cm}$ containers 6 to 8 months after rooted cuttings are potted. In smaller containers $(10 \mathrm{~cm})$, they are ready in 4 to 6 months. Trial blocks were situated in the ground at the National Germplasm Repository, Miami, FL, from plants established in 15-cm containers in Oct. 2005, Apr. 2007, and again in Mar. 2009 in crushed limestone and sand fill substrate similar to urban residential lots in much of South Florida, amended with $8.0 \mathrm{~cm}$ of 10 -year-old aged compost from vegetative solid waste incorporated into the top $15 \mathrm{~cm}$ of the site substrate.

In the landscape, T. diffusa 'Luisa' should be situated in full sun on well-drained soils. It is tolerant of alkalinity to a $\mathrm{pH}$ of at least 8.5 and grows equally well in slightly acidic substrates $(\mathrm{pH}=6.5)$. After establishment, the plant is drought-tolerant, requiring supplementary irrigation only during prolonged periods of no precipitation. Nutritional requirements appear low; we have fertilized field plantings only once annually with no apparent nutritional deficiencies observed. Once each year, the plants should be cut back 

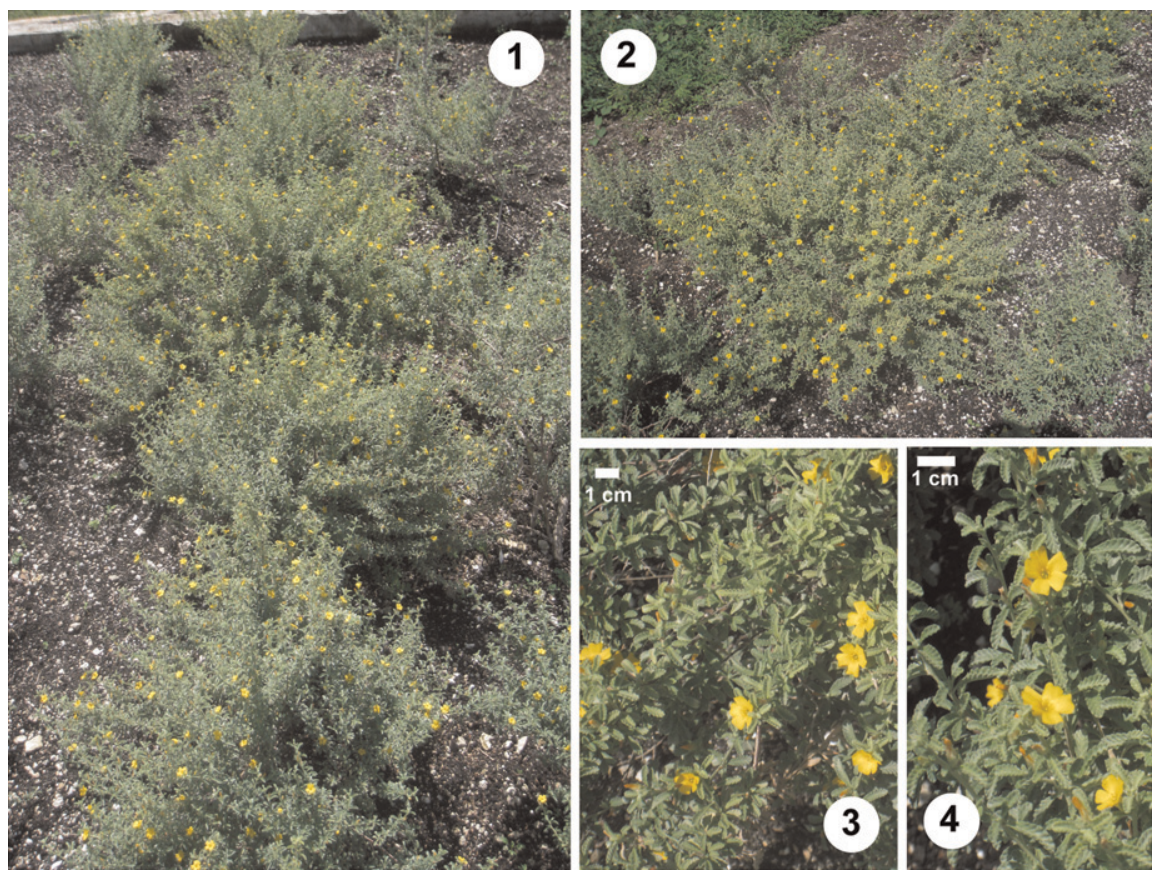

Figs. 1-4. Turnera diffusa 'Luisa'. (Figs. 1-2) Plants after 12 months in the field from 2.7-L containers (Figs. 3-4) Close-up of leaves and flowers.

to half of their height. No pest or disease problems have been observed in 5 years of cultivation history in Miami. Fruit set has never occurred at our location; thus, the threat of potential weediness appears minimal in contrast to T. subulata and ulmifolia, which are adventive in many subtropical and tropical areas (Barrett, 1978; Belaoussoff and Shore, 1995; Kumar et al., 2000). The rapid rate of growth, ease of propagation, and longflowering season suggest that $T$. diffusa 'Luisa' could be marketed as an annual beyond its expected hardiness range, which we estimate to be USDA 9B-11 (U.S. Department of Agriculture, 1990). Flowering occurs for most of the year in South Florida, stopping production only in the coldest months of winter (January to February). Turnera diffusa 'Luisa' can be used as edging, ground cover, bedding, or as a container plant. Although the flowers are small, they are produced in great profusion and contrast well with the gray-green foliage, creating a conspicuous presentation in the landscape. The dwarf growth habit and small leaves and flowers are markedly different from the coarse, rangy habit of the large-flowered $T$. ulmifolia and T. subulata.

\section{Availability}

Small quantities of $T$. diffusa 'Luisa' are available for research and further evaluation purposes by request through the USDA-ARS National Plant Germplasm System (http://www. ars-grin.gov/npgs/) as accession PI 659752.

\section{Literature Cited}

AGP. 2009. An update of the Angiosperm Phylogeny Group classification for the orders and families of flowering plants: APG III. Bot. J. Linn. Soc. 161:105-121.
Arletti, R., A. Benelli, E. Cavazzuti, G. Scarpetta, and A. Bertolini. 1998. Stimulating property of Turnera diffusa and Pfaffia paniculata extracts on the sexual behavior of male rats. Psychopharmacology (Berl.) 143:15-19.

Armitage, A.M. 2004. Armitage's garden annuals: A color encyclopedia. Timber Press, Portland, OR.

Ayala-Silva, T. and A.W. Meerow. 2006. Evaluation of flower color using a Colorimeter and the Royal Horticultural Society Charts. Proc. Int. Trop. Hort. Soc. 50:138-144.

Ayala-Silva, T., R.J. Schnell, A.W. Meerow, M. Winterstein, C. Cervantes, and J.S. Brown. 2005. Determination of color and fruit traits of half-sib families of mango (Mangifera indica L.). Proc. Fla. State Hort. Soc. 118: 253-257.

Barrett, S.C.H. 1978. Heterostyly in a tropical weed: The reproductive biology of the Turnera ulmifolia complex (Turneraceae). Can. J. Bot. 56:1713-1725.

Belaoussoff, S. and J.S. Shore. 1995. Floral correlates and fitness consequences of mating-system variation in Turnera ulmifolia. Evolution 49: 545-556.

Estrada-Reyes, R., P. Ortiz-López, J. GutiérrezOrtíz, and L. Martínez-Mota. 2009. Turnera diffusa Wild (Turneraceae) recovers sexual behavior in sexually exhausted males. J. Ethnopharmacol. 123:423-429.

Kumar, M.S.B., D. Rahi, and R. Vinesh. 2000 Turnera subulata J. E. Sm. (Turneraceae)-A fast naturalizing weed in Indian subcontinent. J. Econ. Taxon. Bot. 24:300-302.

Llamas, K.A. 2003. Tropical flowering plants: A guide to identification and cultivation. Timber Press, Portland, OR.

Mabberly, D.J. 1997. The plant book: A portable dictionary of the higher plants. Cambridge University Press, Cambridge, UK.

Meerow, A.W. and T. Ayala-Silva. 2008. 'Miami Sunrise', 'Miami Sunset', 'Tangelo': Three cultivars of Tecoma guarume. HortScience 43:546548.

Messer, E. 1991. Systematic and medicinal reasoning in Mitla folk botany. J. Ethnopharmacol. $33: 107-128$

Royal Horticultural Society. 1995. RHS Color Chart. 3rd Ed. Royal Horticultural Society, London, UK.

U.S. Department of Agriculture. 1990. USDA plant hardiness zone map. USDA miscellaneous publication No. 1475, Washington, DC.

Zhao, J.R., S. Pawar, Z. Ali, and I.A. Khan. 2007. Phytochemical investigation of Turnera diffusa. J. Nat. Prod. 70:289-292. 